United States Department of Commerce

Technology Administration

National Institute of Standards and Technology

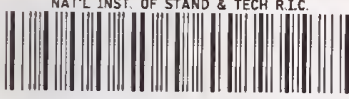

NIST

Al1103 808774

PUBLICATIONS

NIST Special Publication 836

Abstract and Index Collection in the Research Information Center of the National Institute of Standards and Technology

\title{
Diane Cunningham
}

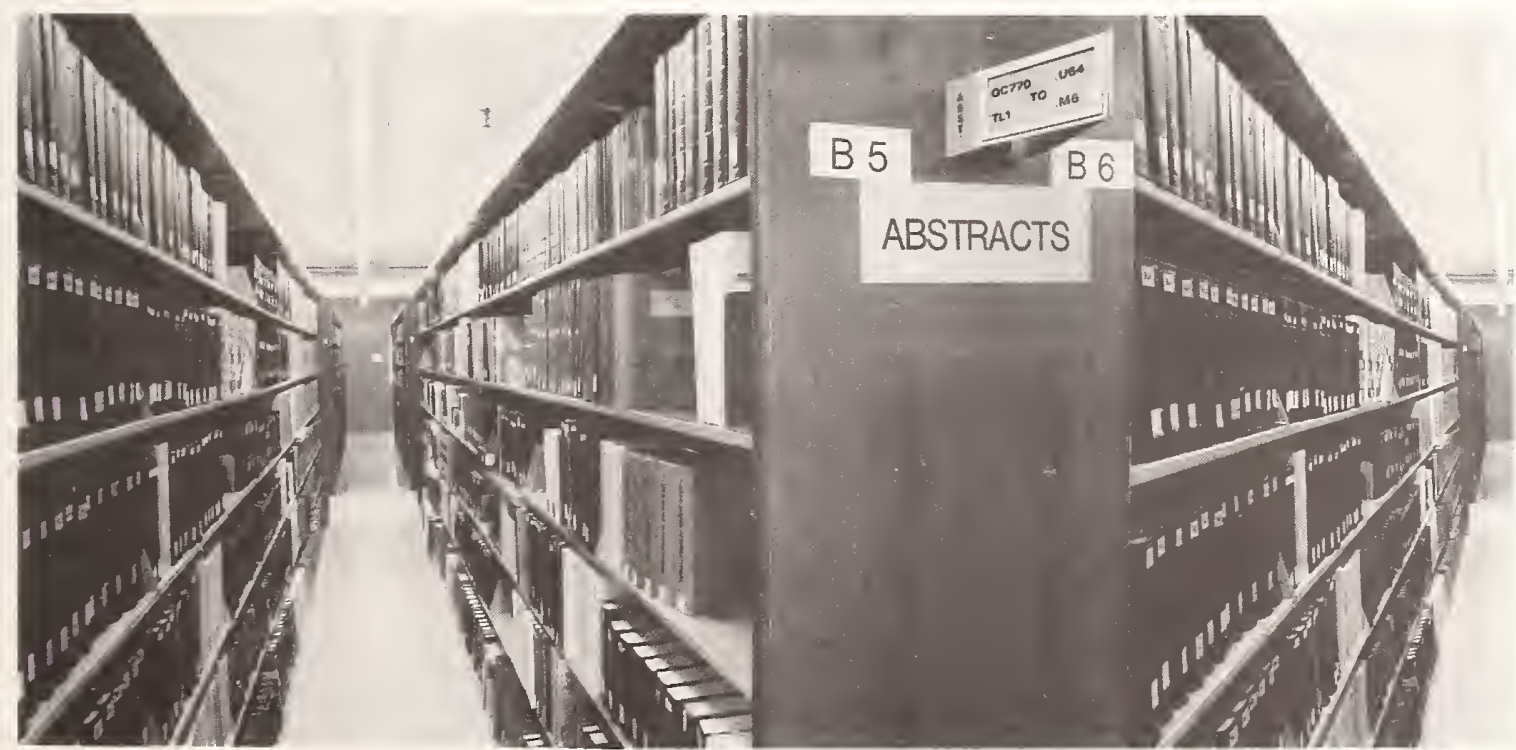

$Q C$
100
.457
836
1992
$C .2$


he National Institute of Standards and Technology was established in 1988 by Congress to "assist industry in the development of technology ... needed to improve product quality, to modernize manufacturing processes, to ensure product reliability ... and to facilitate rapid commercialization . . . of products based on new scientific discoveries."

NIST, originally founded as the National Bureau of Standards in 1901, works to strengthen U.S. industry's competitiveness; advance science and engineering; and improve public health, safety, and the environment. One of the agency's basic functions is to develop, maintain, and retain custody of the national standards of measurement, and provide the means and methods for comparing standards used in science, engineering, manufacturing, commerce, industry, and education with the standards adopted or recognized by the Federal Government.

As an agency of the U.S. Commerce Department's Technology Administration, NIST conducts basic and applied research in the physical sciences and engineering and performs related services. The Institute does generic and precompetitive work on new and advanced technologies. NIST's research facilities are located at Gaithersburg, MD 20899, and at Boulder, CO 80303. Major technical operating units and their principal activities are listed below. For more information contact the Public Inquiries Desk, 301-975-3058.

\section{Technology Services}

- Manufacturing Technology Centers Program

- Standards Services

- Technology Commercialization

- Measurement Services

- Technology Evaluation and Assessment

- Information Services

\section{Electronics and Electrical Engineering} Laboratory

- Microelectronics

- Law Enforcement Standards

- Electricity

- Semiconductor Electronics

- Electromagnetic Fields ${ }^{1}$

- Electromagnetic Technology ${ }^{1}$

\section{Chemical Science and Technology}

Laboratory

- Biotechnology

- Chemical Engineering ${ }^{1}$

- Chemical Kinetics and Thermodynamics

- Inorganic Analytical Research

- Organic Analytical Research

- Process Measurements

- Surface and Microanalysis Science

- Thermophysics ${ }^{2}$

\section{Physics Laboratory}

- Electron and Optical Physics

- Atomic Physics

- Molecular Physics

- Radiometric Physics

- Quantum Metrology

- Ionizing Radiation

- Time and Frequency ${ }^{1}$

- Quantum Physics ${ }^{1}$
Manufacturing Engineering Laboratory

- Precision Engineering

- Automated Production Technology

- Robot Systems

- Factory Automation

- Fabrication Technology

Materials Science and Engineering Laboratory

- Intelligent Processing of Materials

- Ceramics

- Materials Reliability ${ }^{1}$

- Polymers

- Metallurgy

- Reactor Radiation

Building and Fire Research Laboratory

- Structures

- Building Materials

- Building Environment

- Fire Science and Engineering

- Fire Measurement and Research

Computer Systems Laboratory

- Information Systems Engineering

- Systems and Software Technology

- Computer Security

- Systems and Network Architecture

- Advanced Systems

Computing and Applied Mathematics Laboratory

- Applied and Computational Mathematics ${ }^{2}$

- Statistical Engineering ${ }^{2}$

- Scientific Computing Environments ${ }^{2}$

- Computer Services ${ }^{2}$

- Computer Systems and Communications ${ }^{2}$

- Information Systems

${ }^{1}$ At Boulder, CO 80303.

${ }^{2}$ Some elements at Boulder, CO 80303. 


\section{Abstract and Index Collection in the Research Information Center of the National Institute of Standards and Technology}

Diane Cunningham

Office of Information Services

National Institute of Standards and Technology

Gaithersburg, MD 20899

(Supersedes NIST Special Publication 803)

June 1992

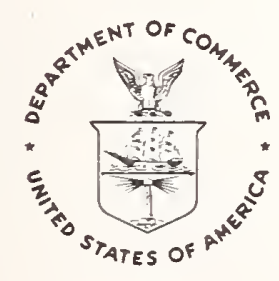

U.S. Department of Commerce

Barbara Hackman Franklin, Secretary

Technology Administration

Robert M. White, Under Secretary for Technology

National Institute of Standards and Technology

John W. Lyons, Director 
National Institute of Standards and Technology Special Publication 836

Natl. Inst. Stand. Technol.

Spec. Publ. 836

(Supersedes NBS Spec. Publ. 803)

35 pages (June 1992)

CODEN: NSPUE2
U.S. Government Printing Office

Washington: 1992

For sale by the Superintendent of Documents

U.S. Government Printing Office Washington, DC 20402 


\section{PREFACE}

This publication lists the major abstracts and indexes available in the collection of the Research Information Center (RIC) of the National Institute of Standards and Technology (NIST). It supersedes and revises NIST Special Publication 803, which is dated December 1990. Entries in the main index, which are arranged alphabetically, include the current title of the abstract or index, RIC's holdings, major sources used to compile information, publisher or publishing association, corresponding RIC online database with CD-ROM availability, RIC call number, and collection/area designation.

Unless otherwise designated, abstracts and indexes are located in the "Abstracts" section on the first floor of the RIC. Other areas and locations which include selected abstracts and indexes are designated by the following:

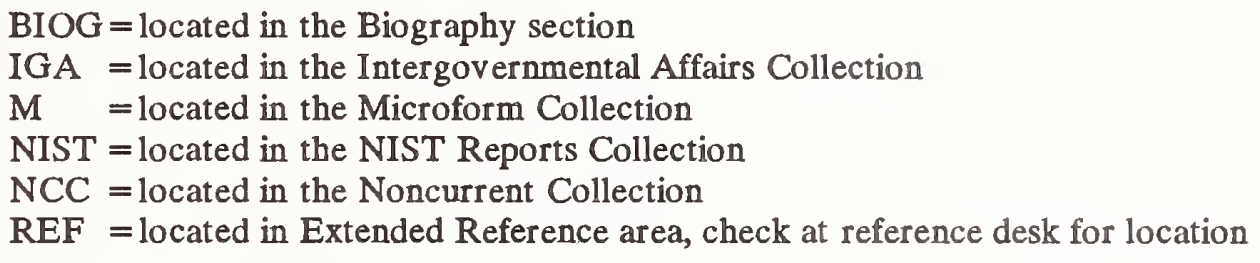

In addition to being listed by current title, abstracts and indexes are grouped in a general subject index. They are also listed by their former titles and by their database names.

I wish to thank Karen Jones for her able assistance and diligence in preparing this publication.

Diane Cunningham

Research Information Services 



\section{CONTENTS}

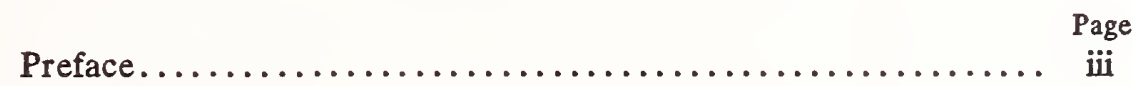

Abstracts/Indexes............................... 1

Noncurrent Collection........................... 20

General Subject Index.......................... 21

Former Title/Database Name Index................. 29 



\section{ABSTRACTS/INDEXES}

\begin{abstract}
INDEX HOLDINGS
\end{abstract}

ACM GUIDE TO COMPUTING LITERATURE

1977-
DESCRIPTION/ SOURCES
PUBLISHER/ASSOCIATION

DATABASE

CALL NUMBER

Index to the literature of computing and related disclipines

Journals, Books, Proceedings,

Reports, Theses
Association for Computing

Machinery (ACM)

QA

76

MATHSCI*
ABSTRACT BULLETIN OF THE
INSTITUTE OF PAPER SCIENCE
AND TECHNOLOGY

v. $1,1930 / 31-v .60,1990$

ABSTRACT JOURNAL IN EARTHQUAKE ENGINEERING

v. 1, 1971-

AMERICAN STATISTICS

INDEX: INDEXES/ABSTRACTS

1974-1984

ANALYTICAL ABSTRACTS

v. 1,1954

APPLIED MECHANICS REVIEWS

v. 1, 1948-v. 40,1987

Journals
Institute of Paper Science and

Technology

principles and technologies

of pulp, paper, and board

manufacturing

Journals, Patents

Comprehensive literature in

earthquake hazard mitigation

Earthquake Engineering Research

Center

TA

658.44

.A25
Z

7914

.P2A6
International literature in engineering sciences Journals, Books

Index and abstracts to statistical publications of the U.S. government

Journals, Reports

International literature dealing with all branches of analytical chemistry

Journals
The Royal Society of Chemistry QD (U.K.)

71

. $\mathrm{A} 49$
Congressional Information Service (CIS)

HA 195 .A 52

ASI

* Some years are available in CD-ROM format. 
APPLIED SCIENCE AND TECHNOLOGY INDEX
Cumulative subject index to

English language journals in the fields of aeronautics and space science, computer technology, chemistry, construction, energy resources, electricity and electronics, engineering, industrial and mechanical arts, etc.
v. 1, 1913-
Journals

H. W. Wilson Co.

Z 7913

.17

WILSON APPLIED SCIENCE AND TECHNOLOGY INDEX

ASTRONOMY AND ASTROPHYSICS ABSTRACTS

v. 1, 1969-

ATOMIC ABSORPTION AND EMISSION SPECTROMETRY ABSTRACTS

v. $1,1969-$-v. 17,1985
Worldwide astronomical publications

Journals
Astronomisches Rechen-Institut/ (Germany)/Springer Verlag

QB

1

.A862
Worldwide documentation of all aspects of atomic absorption and emission spectrometry

Journals, Proceedings, Unpublished Reports
PRM Science and Technology Agency Ltd. (U.K.)

QD

95

.A7
Scientific and technical literature published in Australian journals
Commonwealth Scientific and

M

\section{INDEX}

v. $22,1978-$ v. 27,1983

BNF NON-FERROUS

METALS ABSTRACTS

(British Non-Ferrous

Metals Resource Assoc.)

1970-1983

Journals, Patents, Books
Published information on nonferrous metallurgy and technology Industrial Research Organization (CSIRO) (Australia)

Journals
The BNF Metals Technology Centre (U.K.)

TA

459

.B71

\section{BIOGRAPHY INDEX}

v. $1,1949-$-v. 41,1987
Cumulative index to biographical material

Books, Periodicals
H. W. Wilson Co.

NON-FERROUS METALS ABSTRACTS

\begin{tabular}{llll}
\hline BIOTECHNOLOGY & Literature concerning all & Cambridge Scientific Abstracts & TP \\
RESEARCH ABSTRACTS & aspects of biotechnology & & 248.2 \\
& & & .B582 \\
v. 3, 1986- & Journals & BIOTECHNOLOGY RESEARCH
\end{tabular}

- Some years are available in CD-ROM format. 
ABSTRACT/INDEX

HOLDINGS

DESCRIPTION/

SOURCES
PUBLISHER/ASSOCIATION

DATABASE
BRITISH CERAMIC

ABSTRACTS

1978-1988
International literature of ceramics

Patents, Journals
British Ceramic Research TP

Ltd. $\quad 785$

\section{BUILDING SCIENCE \\ ABSTRACTS}

v. $1,1925-v .49,1976$
Literature of materials, design, and building research

Journals, Reports
Her Majesty's Stationery

Office

TH

1

.G7

\section{BUSINESS PERIODICALS} INDEX

v. $1,1958-$

CA REVIEWS INDEX (CARI)

v. $86,1977-v .97,1982$

CIS INDEX/ANNUAL

1970-
Index to journals in the fields of accounting, advertising, banking and finance, business, insurance, labor and management, taxation, personnel administration, etc.

Journals
H. W. Wilson Co.

HF

5001

.B8

\section{WILSON BUSINESS}

PERIODICALS INDEX

A key word in context (KWIC) index to all reviews that appear in CHEMICAL ABSTRACTS

Journals
Royal Society of Chemistry

QD

1

.A.5124

(Shelved with CHEMICAL ABSTRACTS)
Index to congressional publications

Hearings, Public Laws, Reports, Bills
Congressional Information Service $\mathrm{KF}$

(CIS)

49

. $\mathrm{C} 621$

IGA
CSIRO ABSTRACTS (Commonwealth Scientific and Industrial

Research Organization)

v. 1, 1952-v. 22,1974

\section{CSIRO INDEX}

1975-1986
Abstracts of CSIRO published papers and translations

Journals, Reports, Proceedings
CSIRO Central Information (Australia)
Q

4

.A9
CSIRO Central Information

(Australia)
Q

179.9

.A9

(M-Later years only)

\section{Index of CSIRO published \\ Journals, Translations, Reports}

American Ceramic Society

TP

785

AMERICAN CERAMIC ABSTRACTS 
ABSTRACT/INDEX

HOLDINGS

DESCRIPTION/ SOURCES
PUBLISHER/ASSOCIATION

DATABASE
CHEMICAL ABSTRACTS

v. 1, 1907-
Comprehensive worldwide literature of chemistry, including biochemistry and chemical engineering

Journals, Patents, Books, Reviews
American Chemical Society

CHEMICAL ABSTRACTS
QD

1

.A51 (Located after unbound journals in back of RIC)
CHINA SCIENCE AND TECHNOLOGY ABSTRACTS

Series I: Mathematics, Astronomy, Physics
English abstracts of scientific and technical periodicals in China

International Information Service, Ltd. (Hong Kong)
Q

1 . $\mathrm{C} 45$
Periodicals

\section{CHINA SCIENCE AND \\ TECHNOLOGY ABSTRACTS}

Series II: Chemistry, Earth

Science, Energy Sources
English abstracts of scientific and technical periodicals in China

International Information Service, Ltd. (Hong Kong)
Q

1 .$C 455$
Periodicals, Proceedings v. $6,1985-$-v. 8,1987

CHINA SCIENCE AND TECHNOLOGY ABSTRACTS

Series III: Industrial

Technology

v. 2,$1981 ;$ v. $5,1984-$ v. 8,1987
Comprehensive index to articles in Chinese scientific and technical publications
International Information Service, Ltd. (Hong Kong)
Q

1 . $\mathrm{C} 46$

Periodicals

Abstracts of important scientific articles from the Chinese literature

\section{Science Press (Beijing)}

Q

1 . $\mathrm{C} 42$
Part A: Mathematics, Mechanics, Astronomy and Space, Physics, Technical Sciences

1982-1989
Periodicals, Proceedings
CHINESE SCIENCE ABSTRACTS

Part B: Chemistry, Life

Sciences, Earth Sciences

1982-1989

CIVIL ENGINEERING

HYDRAULICS ABSTRACTS

v. $3,1970-$ - 20,1987
Abstracts of important scientific articles from the Chinese

literature

Periodicals, Proceedings
Science Press (Beijing)

Q

1 . $\mathrm{C} 44$
Worldwide literature of applied fluid mechanics

Journals, Reports, Proceedings
BHRA (The British Hydromechanics Research Association)

FLUIDEX
TC

1

. $\mathrm{C} 15$

\section{COMPUTER ABSTRACTS}

v. 4, 1960-
International literature on computer applications

Journals, Reports, Patents, Books
Technical Information Co.

Ltd. (U.K.)

QA

76 
COMPUTER AND CONTROL ABSTRACTS (Science Abstracts Series C)

v. $1,1966-$
Worldwide coverage of the literature of all aspects of computers and control

Journals, Reports, Books, Dissertations, Patents, Proceedings
INSPEC, Institution of Electrical TJ

Engineers (U.K.)/Institute of 212

Electrical and Electronics .C61

Engineers, Inc.

INSPEC

\section{COMPUTER LITERATUE INDEX}

v. $13,1983-$
Literature in computer science, not including the more esoteric and academic literature
Applied Computer Research, Inc. QA

76

. $\mathrm{C} 565$

Journals

Critical reviews of the current publications in any area of the computing sciences

Books, Journals, Proceedings
Association for Computing

Machinery (ACM)

QA

76

.C6 v. $1,1960-$ v. 22,1981 ;

v. 25,1984
International literature of developments in concrete and concrete technology
American Concrete Institute

TA

439

. $\mathrm{C} 56$

v. 3, 1974-

Journals, Reports, Books

CONSUMERS INDEX TO PRODUCT EVALUATIONS AND INFORMATION SOURCES

v. 4, 1976-v. 17, 1989

CORROSION ABSTRACTS

v. 1, 1962-

CORROSION CONTROL ABSTRACTS

1969-1987
Index to product evaluations and general consumer information
Pierian Press

TS

156.25

. . 65

Journals

Worldwide corrosion control literature

Journals, Proceedings, Reports
National Association of Corrosion Engineers (NACE)

$-$
TA

462

. $\mathrm{C} 652$

\section{CUMULATIVE INDEX TO ASCE PUBLICATIONS}

Translation of Russian journal on corrosion and protection against corrosion

Journals, Patents
Scientific Information Consultants Ltd. (U.K.)
TA

462

. $\mathrm{C} 654$
Index to the publications of the American Society of Civil Engineers

American Society of Civil

Engineers
TA

1 .$A 58$ A5 
CURRENT INDEX OF COMPUTER LITERATURE

v. 1,1985
Listing of the table of contents of computer journals

Journals
Information Research Institute, Inc.
QA

76

. $\mathrm{C} 78$

\section{CURRENT INDEX TO}

STATISTICS; APPLICATIONS, METHODS AND THEORY

v. 1, 1975-

CURRENT PHYSICS INDEX

v. $1,1975-$

\section{CURRENT TECHNOLOGY} INDEX

v. 3, 1964
Comprehensive coverage of statistics, its applications, methods, and theory

Journals

International literature concerning all aspects of physics research and index to CURRENT PHYSICS MICROFORM

Journals

Subject guide to the literature

in British technical journals

Journals
American Statistical Association and Institute of Mathematical Statistics

HA

1

. $\mathrm{C} 9$

MATHSCI*

American Institute of Physics

(AIP)

QC

1 . $\mathrm{C} 786$

SPIN

Bowker-Saur Ltd.

$\mathrm{T}$

1

. $\mathrm{C} 8$

CURRENT TECHNOLOGY INDEX

InterDok Corp.

Z

Bibliography citing published proceedings

Proceedings
Abstracts of international doctoral dissertations from participating universities; master's dissertations for later years

Dissertations
University Microfilms

International
Z 5053

.D5

(M-Scattered years)

1862

DISSERTATION ABSTRACTS ONLINE

Engineering Information, Inc. Z

International engineering conference literature

Proceedings
International literature covering all aspects of electrical and electronics engineering

Journals, Reports, Books, Dissertations, Patents, Proceedings
INSPEC, Institution of Electrical Engineers (U.K.)/Institute of Electrical and Electronics Engineers, Inc.

INSPEC
Z 5851 .E6 TRONICS ABSTRACTS

(Science Abstract Series B)

v. 1, 1898-
COMPENDEX*

\footnotetext{
- Some years are available in CD-ROM format.
} 
ELECTROANALYTICAL ABSTRACTS

v. $1,1963-$ - 23,1985
International journal dealing with the documentation of all aspects of fundamental, physicochemical and analytical electrochemistry

Journals, Reviews, Books
Birkhăuser Verlag (Switzerland) QD

551

. $\mathrm{J} 62$
The Institution of Electrical TK

Engineers/Institute of Electrical 7870

and Electronics Engineers, Inc. .E38

no. 1, 1976-1989

Journals

ELECTRONICS AND COMMUNICATIONS ABSTRACTS

v. $1,1961-$
Worldwide publications in measurement science and instrumentation
Multi-Science Pub. Co.

Ltd. (U.K.) electronics and communications

Journals, Proceedings,

Unpublished Reports
TK

5101

.A1E48

\section{ENERGY RESEARCH ABSTRACTS}

1975-1987
Dept. of Energy and U.S. government-sponsored research on all aspects of energy

Journals, Reports
U.S. Dept. of Energy, Office of Scientific and Technical Information

\section{ENERGY SCIENCE AND TECHNOLOGY}

TJ

163.2

.U54

\section{ENGINEERING DATA BANK ABSTRACTS/INDEX OF REPORTS}

1977-1988

v. 1,1884

ERGONOMICS ABSTRACTS

v. $6,1974-v .19,1987$

Engineering evaluation and qualification test reports, nonstandard parts justification data, parts/materials specifications, manufacturing processes, etc.

\section{Government Industry Data} Exchange Program (GIDEP)
TS

170

.E5

Reports, Technical Data

GIDEP

Transdisciplinary index to the world's engineering literature

Journals, Conference Papers
Engineering Information, Inc.

COMPENDEX*
$\mathbf{Z}$ 5851

.E62
International literature on human factors in man-machine systems and physical environmental influences
Taylor and Francis

TA

166

. $\mathrm{E7132}$

Journals, Proceedings, Reports, Book Reviews

\footnotetext{
- Some years are available is - $\quad$ f format.
} 
FAILURE EXPERIENCE

DATA BANK SUMMARY

1978-1987
FIVE-YEAR INDEX TO ASTM TECHNICAL PAPERS AND REPORTS

1898-1970;

1976-1980
Data on failure information generated whenever significant problems are identified on parts, materials, or safety

Reports, Technical Data
Government Industry Data Exchange Program (GIDEP)

173

.F3
GIDEP
Index to the publications of the American Society For Testing and Materials

American Society For Testing and Materials (ASTM)

TA

401

. $\mathrm{A} 525$
Journals, Special Technical Pub-

lications
FOREIGN TECHNOLOGY

1984
Listing of current technical foreign reports available from the National Technical Information Service
National Technical Information T

Service (NTIS)

1

NTIS

Institute of Gas Technology TP

700

.G13

v. $1,1945-$

v. 38,1982

GAS AND LIQUID CHROMATOGRAPHY LITERATURE

v. $1,1992-$

GAS CHROMATOGRAPHY LITERATURE, ABSTRACTS AND INDEXES

International literature on gas chromatography

Preston Publications QD International literature on gas and liquid chromatography

Preston Publications

QD

.A1G31
1

. $\mathrm{A} 1 \mathrm{G} 3$
v. $2,1969-$ v. 24,1991
Journals, Conference Papers

GIDEP INDEX OF REPORTS

1990
Index to reports from the Government Industry Data

Exchange Program
Government Industry Data Exchange Program (GIDEP)
TS

170

. $\mathrm{E52}$
Reports
GIDEP 
GOVERNMENT REPORTS

ANNOUNCEMENTS AND

INDEX

v. $1,1946-$
Listing of government and government-sponsored research and development reports

Reports, Journals, Proceedings
National Technical Information

Service (NTIS)

Z

7916

.B47
INDEX OF MATHEMATICAL PAPERS

v. $1,1970-$-v. 9, 1979

INDEX TO SCIENTIFIC AND TECHNICAL PROCEEDINGS

1978-

INDEX TO SCIENTIFIC BOOK CONTENTS

1986-1987

INDEX TO SCIENTIFIC REVIEWS

v. $1,1975-1987$
An author and subject index of all papers and books reviewed in MATHEMATICAL REVIEWS
American Mathematical Society

NTIS*
Journals, Books

Multidisciplinary listing of published proceedings

Proceedings

Index to the chapters in scientific books

Books
QA

1

M762

MATHSCI ${ }^{*}$

Institute for Scientific $\quad Q$

Information (ISI) 101

.I5

ISTP REF

\section{INDEX TO STATISTICS AND PROBABILITY}

1973-1975

INFORMATION SCIENCE ABSTRACTS

\section{v. 1, 1966-}

INIS ATOMINDEX (International Nuclear Information System)

v. 6, 1975-
International interdisciplinary index to the review literature of science, medicine, agricultural sciences, technology, and the behavioral sciences
Institute for Scientific

Information (ISI)

7401

.145
Institute for Scientific $\quad \mathrm{Z}$

Information (ISI)

.15

International literature of statistics and probability

Journals
R \& D Press

\section{Z}

6654

. $\mathrm{M} 33 \mathrm{~T} 84$

MATHSCI*

Plenum Pub. Corp.

International literature in the fields of information science, documentation, and related areas

Books, Journals, Conference Proceedings, Reports, Patents
INFORMATION SCIENCE ABSTRACTS

\section{1 \\ 5}

International literature of nuclear science relating to its peaceful applications

Reports, Journals, Theses, Proceedings
International Atomic Energy $\quad$ QC

Agency (Austria) $\quad 770$

.I2

- Some years are available in CD-ROM format. 
INTERNATIONAL ABSTRACTS IN OPERATIONS RESEARCH

v. 1, 1961-
Worldwide literature in operations research

Journals
MacMillan Press Ltd. (U.K.) T

58

. .A215

\section{INTERNATIONAL AEROSPACE} ABSTRACTS

v. 1, 1961-v. 26,1986
Comprehensive international literature of aerospace science and technology

Journals, Books, Proceedings, Translations
American Institute of Aeronautics TL and Astronautics, Inc.

TI
501
.$I 53$

TI
501
.$I 53$

1

AEROSPACE DATABASE

John Wiley and Sons Ltd.

TN

860

. $\mathrm{I} 53$
Worldwide coverage of petroleum and allied literature concerning oil field exploration and development, petroleum refining and products, and economics

Journals

v. $1,1973-$

JAPAN BIOSCIENCES

v. 1,1988

JAPAN CHEMISTRY

v. 1,1988

JAPAN COMPUTERS

v. 1,1988

JAPAN ELECTRONICS

v. 1,1988
Summaries of current Japanese research information on biochemistry, drugs, molecular and cell biology, bioengineering, food processing, etc.
University Microfilms, Inc.

QH

301

.J36

Journals

Summaries of current Japanese research information on crystals, kinetics, polymers, chemical engineering, etc.
University Microfilms, Inc.

1

.J36

Journals

Summaries of current Japanese research information on CAD/

University Microfilms, Inc.

QA

76.5

.J36

CAM, robots, artificial intelligence, software engineering, etc.

Journals

Summaries of current Japanese research information on circuits, sensors, superconducting materials, acoustic devices, etc.

\section{University Microfilms, Inc.}

TK

1

.J36

\section{Journals}


ABSTRACT/INDEX HOLDINGS

JAPAN ENERGY

v. 1,1988

JAPAN MANUFACTURING

v. 1,1988

JAPAN MATERIALS

v. 1,1988

JAPANESE TECHNICAL ABSTRACTS

v. 1, 1986-v. 2, 1987

JOURNAL OF CURRENT

LASER ABSTRACTS

v. 1,1964
DESCRIPTION/

SOURCES
PUBLISHER/ASSOCIATION

DATABASE

CALL NUMBER
Summaries of current Japanese research information on geophysics, nuclear power plants, energy conservation, super-

conductivity, etc.
University Microfilms, Inc.

HD

9502

.J36

Journals

Summaries of current Japanese research information on inventory control, production management, machinery, heat transfer, etc.

Journals
University Microfilms, Inc. TS

183

.J36
Summaries of current Japanese research on composites, metallurgy, powder technology, ceramics, textiles, etc.
University Microfilms, Inc.

TA

401

.J355

Journals

Japanese Technical Information $T$ Service, University Microfilms 1

Inc. of technology, applied sciences, engineering, and business management

Journals

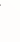

.J32
International comprehensive literature on laser theory, design, and application
TK 7871.3 .$J 65$

Journals, Proceedings, Reports, Patents, Dissertations, Books

American Economic Association $\quad$ HB 1

.J6

(M-Earlier Years)
Literature on economic subjects in English language journals
Book Reviews, Journals
JOURNAL OF ECONOMIC
v. $1,1963-$
JOURNAL OF EC
LITERATURE
LIBRARY AND INFORMATION SCIENCE ABSTRACTS (LISA)
1969
International literature of
library and information science
Journals

Bowker-Saur Ltd. (U.K.)

Z

671

. $\mathrm{L} 617$ 
ABSTRACT/INDEX

HOLDINGS

DESCRIPTION/

SOURCES
PUBLISHER/ASSOCIATION

DATABASE

CALL NUMBER
LIBRARY LITERATURE

1921-1986

\section{MATHEMATICAL REVIEWS}

v. $1,1940-$
Author and subject index to materials on library and information science

Journals, Books, Pamphlets, Films, Theses
H. W. Wilson Co.

666

.$S 211$

WILSON LIBRARY LITERATURE
International coverage and reviews of the literature of mathematics

Journals, Books, Proceedings
American Mathematical Society

QA

1

.M76
MEASUREMENTS IN PHYSICS

1976-1989
International literature in the fields of measurement and metrology
The Institution of Electrical Engineers/Institute of Electrical and Electronics Engineers, Inc.
QC

39

.95

Journals

International literature of metal finishing including extensive patent information

Journals, Patents, Books, Reports

\section{METAL FINISHING ABSTRACTS}

v. $1,1959-$-v. 27,1985
International literature covering the whole field of metallurgy

The Metals and Metallurgy Trust (U.K.)
TS

550

.M32

\section{METALLURGICAL ABSTRACTS}

v. 1, 1934-v. 32, 1965;

v. $1,1966-$ v. 2,1967

\section{METALS ABSTRACTS}

v. $1,1968-$
Worldwide comprehensive literature on metallurgy

Journals, Books, Reports, Proceedings, Dissertations, Patents
The Institute of Materials (U.K.)/ TN ASM International . $\mathrm{M} 5153$

\section{METADEX}

TN

1 .158

Journals, Reports

Index to government and industry data in metrology which is essential in research, design, development, production, and operational phases of the life cycle of systems and equipment
Government Industry Data METROLC

1976-1984
QC 100.5 .U5

* Some years are available in CD-ROM format. 
MICROCOMPUTER INDEX

v. 1,1980

MONTHLY CATALOG OF

UNITED STATES GOVERN-

MENT PUBLICATIONS

1895-1976

MÖSSBAUER SPECTROSCOPY

ABSTRACTS

v. 2, 1979-v. 7, 1984

NASA SCIENTIFIC AND

TECHNICAL PUBLICATIONS

1977-1986

NATIONAL BUREAU OF

STANDARDS INDEX

1979

NUCLEAR SCIENCE

ABSTRACTS

v. 1, 1948-v. 33, 1976

\section{OR/MS OPERATIONS \\ RESEARCH/MANAGEMENT \\ SCIENCE}

v. 9,1969 -v. 29,1989
PAIS INTERNATIONAL IN

PRINT

v. $55,1969-1991$
DESCRIPTION/

SOURCES
PUBLISHER/ASSOCIATION

DATABASE

CALL NUMBER
A subject index to articles in microcomputer magazines

Journals
Learned Information, Inc.

QA

76.5

.M5218
MICROCOMPUTER INDEX
Publication listings of U.S.

Government agencies

Reports, Books, Serials

International literature concern-

ing Mössbauer spectroscopy

Journals, Proceedings, Reports
U.S. Government Printing Office

(GPO)

$\mathrm{Z}$

1223

.A18

(M-Earlier years)
MONTHLY CATALOG
PRM Science and Technology $\quad$ QC

Agency Ltd. (U.K.) 491

. $\mathrm{M} 63$
Catalog of NASA special publications, reference publications, conference publications, and technical papers

Reports, Proceedings

Index to the National Bureau of Standards (NBS) documents on file in the GIDEP Technical

Library

Reports
National Aeronautics and Space

Administration, Scientific and

Technical Information Division
TL

521.312

.N3

\section{NASA/RECON}

\section{Government Industry Data $\quad$ QC}

Exchange Program (GIDEP) 100

.U575
Worldwide comprehensive literature of nuclear science

Reports, Books, Proceedings, Patents, Journals
U.S. Department of Energy

NUCLEAR SCIENCE ABSTRACTS
QC

770

.U64
International literature of operation research and management science
Executive Sciences Institute,

Inc.
HD

20

.06
Journals
Worldwide literature related to economic and social conditions, public administration, and international relations

Books, Pamphlets, Government Publications, Reports, Journals
Public Affairs Information

Z

Service, Inc. 7163 .P9
PAIS 
PHOTOGRAPHIC ABSTRACTS

v. 1, 1921-1987

PHYSICS ABSTRACTS

(Science Abstracts Series A)

v. $1,1898-$
Abstracts of the world literature of the science, technology, and applications of photography

Journals, Patents
The Royal Photographic Society TR of Great Britain/Pergamon 1 Press

\section{1}

.P4
International literature covering the entire field of physics

Journals, Reports, Books, Dissertations, Patents, Proceedings
INSPEC, Institution of Electrical Engineers (U.K.)/Institute of Q Electrical and Electronics Engineers, Inc.

INSPEC
Worldwide literature covering all fields of physics and related topics

Physik Verlag GmbH (West Germany)

Journals, Books, Patents, Reports, Theses, Proceedings

QC

1

.P68

(1920-1978 NCC) v. $1,1920-$ v. 5,1983
Comprehensive world coverage of the literature on printed circuit production and fabrication and of manufacturing and coating techniques and equipment for integrated circuits, semiconductors, connectors, and specialized applications
Finishing Publications Ltd. (U.K.) TK

7868

.P7P74

\section{ELECTRONICS COATINGS} ABSTRACTS v. 7, 1991-
Journals, Patents

\section{PHYSICS BRIEFS}

PUBLICATIONS OF THE NATION- A comprehensive listing of techAL INSTITUTE OF STANDARDS AND TECHNOLOGY

1901nical publications by the U.S. National Institute of Standards and Technology (formerly National Bureau of Standards)

Reports, Journals, Proceedings, Patents
U.S. National Institute of Standards QC and Technology/GPO 100

.U57

SP305

NIST

NTIS*

World's literature in rubber, plastics, and associated fields

Journals, Patents
Rubber and Plastics Research TS Association of Great Britain

RAPRA ABSTRACTS

- Some years are available in CD-ROM format. 
READERS' GUIDE TO

PERIODICAL LITERATURE

v. 29,1969
Cumulative author-subject index to periodicals of general interest covering a wide variety of general subjects

Periodicals
H. W. Wilson Co.

AI

3

.R4

\section{WILSON READERS' GUIDE TO} PERIODICAL LITERATURE

\begin{tabular}{|c|c|c|}
\hline $\begin{array}{l}\text { REFERATIVNYI ZHURNAL: } \\
\text { FIZIKA }\end{array}$ & World's literature in physics & Akademiya Nauk SSSR \\
\hline
\end{tabular}

1960-

Journals, Books, Patents

$\begin{array}{llcl}\text { REFERATIVNYI ZHURNAL: } & \text { World's literature in mathe- } & \text { Akademiya Nauk SSSR } & \text { QA } \\ \text { MATEMATIKA } & \text { matics } & 1 \\ \text { 1966- } & \text { Journals, Books, Patents } & - & . A 373\end{array}$

1966-

Journals, Books, Patents

Akademiya Nauk SSSR

Akademiya Nauk SSSR

World's literature in metals

Journals, Books, Patents

Journals, Books, Patents
QC

1

. $\mathrm{A} 41$

1956-

REFERATIVNYI ZHURNAL: METALLURGIYA

1984-1987

Comprehensive guide to reference materials

Pierian Press

Z

REFERENCE SOURCES

Books

v. 1, 1977-v. 7, 1983

Reliability and maintainability data on parts, components, assemblies, equipment, etc.

Reports, Technical Data

Reviews on complex analysis which appear in MATHEMATICAL REVIEWS

Journals
Government Industry Data

Exchange Program (GIDEP)

TS

173

.R45

1978-1989

\section{REVIEWS IN COMPLEX ANAL YSIS}

1980-1986
GIDEP
TN

1

.R4

- Some years are available in CD-ROM format. 
RHEOLOGY ABSTRACTS

v. 1,1958 -

ROBOTICS ABSTRACTS

v. $1,1983-$ v. 8,1990

ROBOTICS TECHNOLOGY

ABSTRACTS

v. 3, 1984-v. 6, 1987
Worldwide literature in the science and practice of rheology

Journals
British Society of Rheology/

Pergamon Press

QC

189

. $\mathrm{R} 53$

Literature on robot research, Bowker A\&I Pub.

TS

design and application in industrial

191.8

and non-industrial settings

.R55

Journals

Worldwide literature on the manufacture and use of robots

Cranfield Press (U.K.)

TS

191.8

Journals, Reports, Patents,

Proceedings
ROYAL SOCIETY OF
LONDON. CATALOGUE
OF SCIENTIFIC PAPERS

v. $1,1867-$ v. 19,1925
Index to nineteenth century scientific papers
Her Majesty's Stationery Office (HMSO) (U.K.)
Z

7403

.R88
SAFETY SCIENCE ABSTRACTS

v. 1, 1973-v. 9, 1982
International literature devoted to identifying, evaluating, and eliminating or controlling hazards

Journals, Reports, Proceedings, Books, Dissertations, Patents
The Institute of Safety and Systems Management/ Cambridge Scientific Abstracts
$\mathrm{T}$

55

.A1S3

SAFETY

International interdisciplinary index to the literature of chemistry, physics, medicine, agriculture, technology, etc.

Journals

Comprehensive worldwide literature on the science and technology of space and aeronautics Reports, Patents, Dissertations
Institute for Scientific Information (ISI) 7401 .$S 365$

1945-

SCIENTIFIC AND TECHNICAL AEROSPACE REPORTS

v. 1, 1963-v. 29, 1991
U.S. National Aeronautics and Space Administration (NASA)

TL 787 .U51

\footnotetext{
- Some years are available in CD-ROM format.
} 
ABSTRACT/INDEX

HOLDINGS
DESCRIPTION/

SOURCES
PUBLISHER/ASSOCIATIION

DATABASE
Water Resources Scientific TD

Information Center, U.S. Dept. 201

of the Interior S4

WATER RESOURCES

ABSTRACTS

\section{SEVENTY-SEVEN YEAR INDEX - TECHNICAL PAPERS \\ (AMERICAN SOCIETY OF MECHANICAL ENGINEERS)}

1880-1956

\section{SOLID STATE ABSTRACTS JOURNAL}

v. $1,1957-$ v. 9,1968
Index to the publications of the American Society of Mechanical Engineers

American Society of Mechanical Engineers

TJ

1 .A774

Journals

Comprehensive coverage of the world literature on the theory, production, and use of solid state materials and devices
Cambridge Communication Corp. TK

7800

.$\$ 42$

Journals, Books, Reports, Patents, Dissertations, Proceedings

\section{STATISTICAL REFERENCE INDEX (SRI)}

v. $1,1980-$ v. 10,1989
Index and abstracts to American statistical publications from private organizations and state government sources
Congressional Information Service HA

(CIS)

.$S 75$

Directories, Statistical Publications

International literature of statistical mathematics

Journals, Reports, Proceedings
International Statistical Institute

HA

1 .$S 764$

v. 1, 1959-

International literature on developments in the steel industry

Journals
Metals Information

TN

1

.$M 51531$ v. 1, 1983-v. 7, 1989

SURFACE TREATMENT TECHNOLOGY ABSTRACTS

v. $28,1986-$
International literature of metal finishing, surface-treatment, printed circuits, and electronics coatings

Journals, Patents, Books, Reports
Finishing Publications Ltd.

(U.K.)

TP

155.7

.583 


TECHNICAL BOOK REVIEW
INDEX
INDEX

v. $1,1935-$ - $.54,1988$
A monthly index to book reviews of new technical, scientific and medical books covering all fields of the pure sciences, life sciences, medicine, and technology
JAAD Pub. Co.

Z

7913

. $\mathrm{T36}$

Reviews

Listing of abstracts in the chemical engineering literature

Journals, Reports, Books
The Royal Society of Chemistry (U.K.)

TP

1

. $\mathrm{T} 47$

v. 1,1964

Translations into English of technical papers on metals and materials
Institute of Metals/ASM

International
QD

171

.A6

v. $1,1977-$

Journals

\section{TRANSLATIONS REGISTER INDEX}

v. $1,1967-$-v. 20,1986
Listing of unpublished translations into English from the world literature of the natural, physical, medical, and social sciences

Journals
National Translations Center

Z

7401

. $\mathrm{T} 7$

\section{U.S. NATIONAL ADVISORY COMMITTEE FOR AERONAU- TICS. LISTS OF ITS TECHNICAL MEMORANDA, TECHNICAL NOTES, AND WAR TIME REPORTS}

v. $1,1936-$ v. 2,1948

Reports
List of reports published by NACA (U.S. National Advisory

Committee for Aeronautics)
National Advisory Committee for Aeronautics
TL

787

.U51
U.S. NATIONAL AERONAUTICS Listing of unclassified NASA/ AND SPACE ADMINISTRATION. NACA technical publications INDEX OF NASA TECHNICAL PUBLICATIONS

Reports

U.S. National Aeronautics and Z Space Administration (NASA) 5063

\section{3 \\ .U592}

\section{WORLD CERAMIC ABSTRACTS}

1978-
International literature of ceramics

Patents, Journals

\section{Pergamon Press}

TP

785 .W67 
WORLD SURFACE COATINGS ABSTRACTS

v. 42,1969
International literature on paints, varnishes, and allied industries

Reports, Patents, Standards, Journals

Worldwide literature of textiles and the textile industry

Journals, Proceedings, Patents, Standards, Books, Reports
Paint Research Association TP

(U.K.)/Pergamon Press

934

.R4

WORLD SURFACE COATINGS ABSTRACTS
WORLD TEXTILE ABSTRACTS

v. 1,1969
Translations of literature relating to all fields of science and technology
International Translations Centre (The Netherlands)/

British Lending Library
TS

1300

.W6

WORLD TEXTILES

Elsevier Science Publishers Ltd.

(U.K.)
WORLD TRANSINDEX

1967-1982

WORLD TRANSLATIONS INDEX

v. 1, 1987-

X-RAY FLUORESCENCE SPECTROMETRY ABSTRACTS

v. $1,1970-$ v. 15,1984

Journals

Translations in all fields of science and technology

Journals

International literature on

all aspects of $X$-ray

fluorescence spectrometry

Journals, Proceedings, Unpublished Reports
Z

7401

.W62
International Translations Centre $\quad \mathrm{Z}$

7401

.W63
ZENTRALBLATT FÜR MATHEMATIK UND IHRE GRENZGEBIETE: MATHEMATICS ABSTRACTS
World wide literature in mathematics

Springer Verlag

PRM Science and Technology

Agency Ltd. (U.K.)

QD

95

. $\mathrm{X} 2$

v. 1, 1931-v. 358,1978

Books, Journals, Proceedings

MATH

QA

1

.Z5 


\section{NONCURRENT COLLECTION}

\section{ABSTRACT/INDEX}

HOLDINGS

BRITISH ABSTRACTS

SERIES A, B, C

1926-1953

CUMULATIVE BOOK

INDEX

1938-1983

INTERNATIONAL CATALOGUE OF SCIENTIFIC LITERATURE

1901-1914

JAHRBUCH ÜBER DIE

FORTSCHRITTE DER

MATHEMATIK

v. $1,1868-$ v. 68,1942
DESCRIPTION/

SOURCES

International literature of all

aspects of chemistry

Journals, Proceedings

A comprehensive world

list of books in the English

language

Books
PUBLISHER/ASSOCIATION

DATABASE

Bureau of Abstracts (U.K.)

$\begin{array}{ll} & 1 \\ - & . B 68 \\ \text { NCC }\end{array}$

H. W. Wilson Co.

CT

100

. $\mathrm{C} 8$

NCC

QD

B68
CALL NUMBER

Royal Society of London

Z

7401

.162

Journals

$-$

$\mathrm{NCC}$
NATIONAL UNION CATALOG

1898-
Worldwide literature of mathematics

Journals, Books de Gruyter (Germany)

QA

1

.J4

NCC
A listing of works cataloged by the Library of Congress and by the libraries contributing to its cooperation cataloging program

Books, Reports, Journals, Maps, Serials
Library of Congress

Z

881

.A1U372

NCC

LC MARC 


\section{GENERAL SUBJECT INDEX}

SUBJECT

Aerospace and Aeronautical Engineering

Agriculture and Agricultural Engineering

Architecture and Design

Biography

Biotechnology

Building and Construction

Business, Economics, Management

Ceramics

Chemistry and Chemical Engineering
ABSTRACT/INDEX

EI Engineering Conference Index

Engineering Index

Government Reports Announcements and Index

International Aerospace Abstracts

NASA Scientific and Technical Publications

Science Citation Index

Scientific and Technical Aerospace Reports

U.S. National Advisory Committee for Aeronautics. Lists of its Technical Memoranda, Technical Notes, and War Time Reports

U.S. National Aeronautics and Space Administration: Index of NASA Technical Publications

Chemical Abstracts

EI Engineering Conference Index

Engineering Index

Government Reports Announcements and Index

Science Citation Index

Selected Water Resources Abstracts

EI Engineering Conference Index

Engineering Index

Biography Index

Biotechnology Research Abstracts

Building Science Abstracts

Concrete Abstracts

Cumulative Index to ASCE Publications

EI Engineering Conference Index

Engineering Index

Business Periodicals Index

Journal of Economic Literature

OR/MS Operations Research/Management Science

PAIS International in Print

British Ceramic Abstracts

Ceramic Abstracts

Japan Materials

World Ceramic Abstracts

Abstract Bulletin of the Institute of Paper Science and Technology Analytical Abstracts

BNF Non-Ferrous Metals Abstracts

British Abstracts, Series A, B, C (NCC)

British Ceramic Abstracts 


\section{GENERAL SUBJECT INDEX}

\section{SUBJECT}

Chemistry and Chemical Engineering (cont'd)

Civil Engineering

Computer Science

Consumer Information

\section{ABSTRACT/INDEX}

CA Reviews Index

Ceramic Abstracts

Chemical Abstracts

China Science and Technology Abstracts Series II

Corrosion Abstracts

Corrosion Control Abstracts

EI Engineering Conference Index

Electroanalytical Abstracts

Engineering Index

Gas Abstracts

Gas and Liquid Chromatography Literature

Gas Chromatography Literature, Abstracts and Indexes

Government Reports Announcements and Index

Japan Chemistry

Mössbauer Spectroscopy Abstracts

Nuclear Science Abstracts

RAPRA Abstracts

Science Citation Index

Surface Treatment Technology Abstracts

Theoretical Chemical Engineering

World Ceramic Abstracts

World Surface Coatings Abstracts

$\mathrm{X}$-ray Florescence Spectrometry Abstracts

Abstract Journal in Earthquake Engineering

Civil Engineering Hydraulics Abstracts

Corrosion Abstracts

Concrete Abstracts

Cumulative Index to the ASCE Publications

EI Engineering Conference Index

Engineering Data Bank Abstracts/Index of Reports

Engineering Index

Failure Experience Data Index

Government Reports Announcements and Index

Reliability-Maintainability Data Interchange

Science Citation Index

Selected Water Resources Abstracts

ACM Guide to Computing Literature

Computer Abstracts

Computer and Control Abstracts

Computer Literature Index

Computing Reviews

Current Index of Computer Literature

Information Science Abstracts

International Abstracts in Operations Research

Japan Computers

Microcomputer Index

OR/MS Operations Research/Management Science

Consumer Index to Product Evaluations and Information Sources 


\section{GENERAL SUBJECT INDEX}

\section{SUBJECT}

Earth and Space

Electronics and Electrical Engineering

Energy

Environment

Government Reports

Information Science

NCC $=$ Noncurrent Collection

\section{ABSTRACT/INDEX}

Astronomy and Astrophysics Abstracts

China Science and Technology Abstracts Series II

International Aerospace Abstracts

Science Citation Index

Scientific and Technical Aerospace Reports

Selected Water Resources Abstracts

U.S. National Aeronautics and Space Administration. Index of NASA Technical Publications

EI Engineering Conference Index

Electrical and Electronics Abstracts

Electroanalytical Abstracts

Electronic Instrumentation

Electronics and Communications Abstracts

Engineering Index

Government Reports Announcements and Index

Japan Electronics

Printed Circuits and Electronics Coatings Abstracts

Science Citation Index

Solid State Abstracts Journal

Surface Treatment Technology Abstracts

Chemical Abstracts

China Science and Technology Abstracts Series II

Energy Research Abstracts

Government Reports Announcements and Index

Japan Energy

Nuclear Science Abstracts

Science Citation Index

Chemical Abstracts

Engineering Index

Science Citation Index

Selected Water Resources Abstracts

American Statistics Index

Energy Research Abstracts

Government Reports Announcements and Index

Monthly Catalog of United States Government Publications

NASA Scientific and Technical Publications

National Bureau of Standards Index

PAIS International in Print

Publications of the National Institute of Standards and Technology

Scientific and Technical Aerospace Reports

U.S. National Advisory Committee for Aeronautics. Lists of its Technical Memornada, Technical Notes, and War Time Reports

U.S. National Aeronautics and Space Administration. Index of NASA Technical Publications

Information Science Abstracts

Library and Information Science Abstracts

Library Literature

National Union Catalog (NCC) 
Instrumentation

Law and Legislative Processes

Life Sciences/Biology

Mathematics and Statistics

Mechanical Engineering

Medicine

Metrology and Standardization
EI Engineering Conference Index

Electronic Instrumentation

Engineering Index

Measurements in Physics

CIS Index/Annual

PAIS International in Print

Government Reports Announcements and Index

Japan Biosciences

Science Citation Index

Selected Water Resources Abstracts

American Statistics Index

Current Index to Statistics

Government Reports Announcements and Index

Index of Mathematical Papers

Index to Statistics and Probability

Jahrbuch über die Fortschritte der Mathematik (NCC)

Mathematical Reviews

Referativnyi Zhurnal: Matematika

Reviews in Complex Analysis

Science Citation Index

Statistical Reference Index

Statistical Theory and Method Abstracts

Zentralblatt für Mathematik und ihre Grenzgebiete; Mathematics Abstracts

Applied Mechanics Review

EI Engineering Conference Index

Engineering Data Bank Abstracts/Index of Reports

Engineering Index

Ergonomics Abstracts

Failure Experience Data Index

Government Reports Announcements and Index

Japan Manufacturing

Referativnyi Zhurnal: Mekhanika

Reliability-Maintainability Data Interchange

Science Citation Index

Seventy-Seven Year Index-Technical Papers (American Society of Mechanical Engineers)

Government Reports Announcements and Index

Science Citation Index

EI Engineering Conference Index

Electronic Instrumentation

Engineering Index

Measurements in Physics

Metrology Data Bank Index

NCC $=$ Noncurrent Collection 
Mining and Metallurgy

Nuclear Science

Optics

Paints and Protective Coatings

Paper and Paper Industry

Patents
BNF Non-Ferrous Metals Abstracts

Chemical Abstracts

Corrosion Abstracts

Corrosion Control Abstracts

Engineering Index

Government Reports Announcements and Index

Japan Materials

Metal Finishing Abstracts

Metallurgical Abstracts

Referativnyi Zhurnal: Metallurgiya

Metals Abstracts

Science Citation Index

Steels Alert

Surface Treatment Technology Abstracts

World Surface Coatings Abstracts

Chemical Abstracts

Engineering Index

Government Reports Announcements and Index

INIS Atomindex

Nuclear Science Abstracts

Science Citation Index

Atomic Absorption and Emission Spectrometry Abstracts

EI Engineering Conference Index

Engineering Index

Journal of Current Laser Abstracts

Physics Abstracts

Surface Treatment Technology Abstracts

World Surface Coatings Abstracts

Abstract Bulletin of the Institute of Paper Science and Technology

Abstract Bulletin of the Institute of Paper Science and Technology BNF Non-Ferrous Metals Abstracts

British Ceramic Abstracts

Ceramic Abstracts

Chemical Abstracts

Computer Abstracts

Computer and Control Abstracts

Corrosion Control Abstracts

Electrical and Electronics Abstracts

Gas Abstracts

Information Science Abstracts

Journal of Current Laser Abstracts

Metal Finishing Abstracts

Nuclear Science Abstracts

Photographic Abstracts

Physics Abstracts

Physics Briefs; Physikalische Berichte 
Patents (cont'd)

Petroleum and Gas

Photography

Physics

Plastics

Public Administration

Robotics

Safety Science

Science and Technology/Multidisciplinary

\section{RAPRA Abstracts}

Referativnyi Zhurnal: Fizika

Referativnyi Zhurnal: Matematika

Referativnyi Zhurnal: Mekhanika

Referativnyi Zhurnal: Metallurgiya

Safety Science Abstracts

Solid State Abstracts Journal

Surface Treatment Technology Abstracts

World Surface Coatings Abstracts

World Textile Abstracts

Gas Abstracts

International Petroleum Abstracts

Photographic Abstracts

Astronomy and Astrophysics Abstracts

Atomic Absorption and Emission Spectrometry Abstracts

Current Physics Index

Electronic Instrumentation

INIS Atomindex

Journal of Current Laser Abstracts

Measurements in Physics

Mössbauer Spectroscopy Abstracts

Physics Abstracts

Physics Briefs; Physikalische Berichte

Referativnyi Zhurnal: Fizika

Rheology Abstracts

Chemical Abstracts

RAPRA Abstracts

PAIS International in Print

Robotics Abstracts

Robotics Technology Abstracts

Failure Experience Data Index

Safety Science Abstracts

Applied Science and Technology Index

Australian Science Index

CSIRO Abstracts

CSIRO Index

China Science and Technology Abstracts

Chinese Science Abstracts

Cumulative Book Index (NCC)

Current Technology Index

Dissertation Abstracts International

Five-Year Index to ASTM Technical Papers and Reports 
GIDEP Index of Reports

Government Reports Announcements and Index

Index to Scientific and Technical Proceedings

Index to Scientific Book Contents

Index to Scientific Reviews

International Catalogue of Scientific Literature (NCC)

Japanese Technical Abstracts

Metrology Data Bank Index

Monthly Catalog of United States Government Publications

National Bureau of Standards Index

National Union Catalog (NCC)

Publications of the National Institute of Standards and Technology

Readers' Guide to Periodical Literature

Reference Sources

Royal Society of London. Catalogue of Scientific Papers

Science Citation Index

Technical Book Review Index

U.S. National Aeronautics and Space Administration. Index of NASA Technical Publications

World Transindex

World Translations Index

Textile Industry

Translations

Water Resources
World Textile Abstracts

Translations Index

Translations Register Index

World Transindex

World Translations Index

Civil Engineering Hydraulics Abstracts

Selected Water Resources Abstracts 

ASI

ASM Translation Index

Abstracts of Declassified Documents

Aerospace Database

American Ceramic Abstracts

Atomic Absorption and Flame Emission Spectroscopy Abstracts

British Non-Ferrous Metals Research Assn. Bull.

British Technology Index

CARI

CBI

CSIRO Science Index

Channel

Chemical Abstracts Reviews Index

COMPENDEX

Current Physics Microform

Documentation Abstracts

Electrical Measurement and Instrumentation

Energy Science and Technology

Finishing Abstracts

\section{FLUIDEX}

GIDEP

\section{ISTP}

Industrial Arts Index
American Statistics Index

Translations Index

Nuclear Science Abstracts

International Aerospace Abstracts

Scientific and Technical Aerospace Reports

Ceramics Abstracts

Atomic Absorption and Emission Spectrometry Abstracts

BNF Non-Ferrous Metals Abstracts

Current Technology Index

CA Reviews Index

Cumulative Book Index

CSIRO Abstracts

Civil Engineering Hydraulics Abstracts

CA Reviews Index

EI Engineering Conference Index

Engineering Index

Current Physics Index

Information Science Abstracts

Electronic Instrumentation

Energy Research Abstracts

INIS Atom Index

Metal Finishing Abstracts

Civil Engineering Hydraulics Abstracts

Engineering Data Bank Abstracts/Index of Reports

Failure Experience Data Index

GIDEP Index of Reports

Metrology Data Bank Index

Reliability-Maintainability Data Interchange

Index to Scientific and Technical Proceedings

Applied Science and Technology Index 


\section{INSPEC}

Institute of Petroleum Abstracts

Japan Technology

Library Science Abstracts

\section{LISA}

MATH

MATHSCI

METADEX

Metron

NASA/RECON

Non-Ferrous Metals Abstracts

NTIS

\section{PAIS}

\section{PAIS Bulletin}

\section{PAPERCHEM}

Physical Measurements and Instrumentation

Physikalische Berichte

Referativnyi Zhurnal; Korrozerja i Zashchita ot Kovrozu

SRI

Science Abstracts Series A

Science Abstracts Series B
Computer and Control Abstracts Electrical and Electronics Abstracts Physics Abstracts

International Petroleum Abstracts

Japanese Technical Abstracts

Library and Information Science Abstracts

Library and Information Science Abstracts

Zentralblatt für Mathematik und ihre Grenzgebiete: Mathematics Abstracts

ACM Guide to Computing Literature

Current Index to Statistics

Index of Mathematical Papers

Index to Statistics and Probability

Mathematical Reviews

Reviews in Complex Analysis

Metals Abstracts

Electronic Instrumentation Measurements in Physics

Scientific and Technical Aerospace Reports

BNF Non-Ferrous Metals Abstracts

Government Reports Announcements and Index

Publications of the National Institute of Standards and Technology

PAIS International in Print

PAIS International in Print

Abstract Bulletin of the Institute of Paper Science and Technology

Measurements in Physics

Physics Briefs; Physikalische Berichte

Corrosion Control Abstracts (Translation)

Statistical Reference Index

Physics Abstracts

Electrical and Electronics Abstracts 
FORMER TITLE/DATABASE NAME INDEX

Former or Related Title/Database Name

Science Abstracts Series C

SCISEARCH

Semiconductor Electronics

SPIN

STAR

U.S. Atomic Energy Commision. Abstracts of Declassified Documents

Water Resources Abstracts

Wilson Business Periodicals Index

Wilson Readers' Guide to Periodical Literature
See Current Title

Computer and Control Abstracts

Science Citation Index

Solid State Abstracts Journal

Current Physics Index

Scientific and Technical Aerospace Reports

Nuclear Science Abstracts

Selected Water Resources Abstracts

Business Periodicals Index

Readers' Guide to Periodical Literature 

NIST-114A

(REV. 3-89)

\section{U.S. DEPARTMENT OF COMMERCE NATIONAL INSTITUTE OF STANDARDS AND TECHNOLOGY \\ BIBLIOGRAPHIC DATA SHEET}

4. TITLE AND SUBTITLE

Abstract and Index Collection in the Research Information Center of the National Institute of Standards and Technology

5. AUTHOR(S)

Diane Cunningham

\begin{tabular}{l|l|}
\hline 6. PERFORMING ORGANIZATION (IF JOINT OR OTHER THAN NIST, SEE INSTRUCTIONS) & CONTRACT/GRANT NUMBER \\
U.S. DEPARTMENT OF COMMERCE \\
NATIONAL INSTITUTE OF STANDARDS AND TECHNOLOGY \\
GAITHERSBURG, MD 20899
\end{tabular}

9. SPONSORING ORGANIZATION NAME AND COMPLETE ADDRESS (STREET, CITY, STATE, ZIP)

Same as Block 6 .

10. SUPPLEMENTAAY NOTES

Supersedes NIST Special Publication 803 (December 1990)

DOCUMENT DESCRIBES A COMPUTER PROGRAM; SF-185, FIPS SOFTWARE SUMMARY, IS ATTACHED.

11. ABSTRACT (A 200-WORD OR LESS FACTUAL SUMMARY OF MOST SIGNIFICANT INFORMATION. IF DOCUMENT INCLUDES A SIGNIFICANT BIBLIOQRAPHY OA LITERATURE SURVEY, MENTION IT HERE.)

An alphabetical arrangement of abstracts and indexes available in the Research Information Center (RIC) of the National Institute of Standards and Technology (NIST) is listed by most current title of the publication. Other information includes description of the abstract or index, RIC holdings, principal sources, publisher or association, corresponding RIC database and CD-ROM availability and the classification number. A general subject and former title/database name index follow the main text of the report.

12. KEY WORDS (6 TO 12 ENTRIES; ALPHABETICAL ORDER; CAPITALIZE ONLY PROPER NAMES; AND SEPARATE KEY WORDS BY SEMICOLONS) Abstracting and indexing services; abstracts; indexes; National Institute of Standards and Technology

13. AVAILABILITY

$\mathrm{X}$ UNUMITEO

FOR OFFICIAL DISTRIBUTION. DO NOT RELEASE TO NATIONAL TECHNICAL INFORMATION SERVICE (NTIS).

$\mathrm{x}$

ORDER FROM SUPERINTENDENT OF DOCUMENTS, U.S. GOVERNMENT PRINTING OFFICE, WASHINGTON, OC 20402.

X ORDER FROM NATIONAL TECHNICAL INFORMATION SERVICE (NTIS), SPRINGFIELD, VA 22161.
14. NUMBER OF PRINTED PAGES

35

15. PRICE

ELECTRONIC FORM * U.S. G.P.0.:1992-311-891:60027 



\section{Technical Publications}

\section{Periodical}

Journal of Research of the National Institute of Standards and Technology-Reports NIST research and development in those disciplines of the physical and engineering sciences in which the Institute is active. These include physics, chemistry, engineering, mathematics, and computer sciences.

Papers cover a broad range of subjects, with major emphasis on measurement methodology and the basic technology underlying standardization. Also included from time to time are survey articles on topics closely related to the Institute's technical and scientific programs. Issued six times a year.

\section{Nonperiodicals}

Monographs-Major contributions to the technical literature on various subjects related to the Institute's scientific and technical activities.

Handbooks - Recommended codes of engineering and industrial practice (including safety codes) developed in cooperation with interested industries, professional organizations, and regulatory bodies.

Special Publications - Include proceedings of conferences sponsored by NIST, NIST annual reports, and other special publications appropriate to this grouping such as wall charts, pocket cards, and bibliographies.

Applied Mathematics Series-Mathematical tables, manuals, and studies of special interest to physicists, engineers, chemists, biologists, mathematicians, computer programmers, and others engaged in scientific and technical work.

National Standard Reference Data Series-Provides quantitative data on the physical and chemical properties of materials, compiled from the world's literature and critically evaluated. Developed under a worldwide program coordinated by NIST under the authority of the National Standard Data Act (Public Law 90-396). NOTE: The Journal of Physical and Chemical Reference Data (JPCRD) is published bimonthly for NIST by the American Chemical Society (ACS) and the American Institute of Physics (AIP). Subscriptions, reprints, and supplements are available from ACS, 1155 Sixteenth St., NW., Washington, DC 20056.

Building Science Series-Disseminates technical information developed at the Institute on building materials, components, systems, and whole structures. The series presents research results, test methods, and performance criteria related to the structural and environmental functions and the durability and safety characteristics of building elements and systems.

Technical Notes-Studies or reports which are complete in themselves but restrictive in their treatment of a subject. Analogous to monographs but not so comprehensive in scope or definitive in treatment of the subject area. Often serve as a vehicle for final reports of work performed at NIST under the sponsorship of other government agencies.

Voluntary Product Standards-Developed under procedures published by the Department of Commerce in Part 10, Title 15, of the Code of Federal Regulations. The standards establish nationally recognized requirements for products, and provide all concerned interests with a basis for common understanding of the characteristics of the products. NIST administers this program as a supplement to the activities of the private sector standardizing organizations.

Consumer Information Series - Practical information, based on NIST research and experience, covering areas of interest to the consumer. Easily understandable language and illustrations provide useful background knowledge for shopping in today's technological marketplace.

Order the above NIST publications from: Superintendent of Documents, Government Printing Office, Washington, DC 20402.

Order the following NIST publications-FIPS and NISTIRs - from the National Technical Information Service, Springfield, VA 22161.

Federal Information Processing Standards Publications (FIPS PUB) - Publications in this series collectively constitute the Federal Information Processing Standards Register. The Register serves as the official source of information in the Federal Government regarding standards issued by NIST pursuant to the Federal Property and Administrative Services Act of 1949 as amended, Public Law 89-306 (79 Stat. 1127), and as implemented by Executive Order 11717 (38 FR 12315, dated May 11, 1973) and Part 6 of Title 15 CFR (Code of Federal Regulations).

NIST Interagency Reports (NISTIR) - A special series of interim or final reports on work performed by NIST for outside sponsors (both government and non-government). In general, initial distribution is handled by the sponsor; public distribution is by the National Technical Information Service, Springfield, VA 22161, in paper copy or microfiche form. 


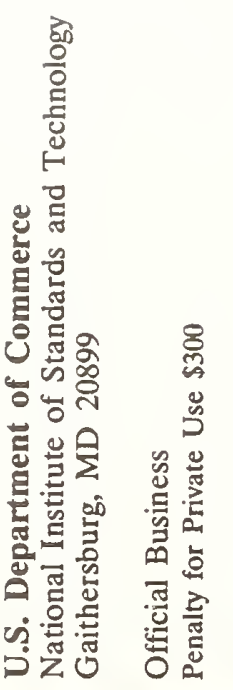

